\title{
ANALISIS LETAK SUMBER AIR RUMAH TANGGA DI WILAYAH KERJA PUSKESMAS MIJEN, SEMARANG TERHADAP BAKTERI ESCHERICHIA COLI
}

\author{
Kanti Ratnaningrum¹, Merry T. Anggraini², Pujangga P.Y. Dahlan³ \\ 1. Bagian Ilmu Kedokteran Tropis, Fakultas Kedokteran Universitas Muhammadiyah Semarang \\ 2. Bagian Ilmu Kedokteran Keluarga, Fakultas Kedokteran Universitas Muhammadiyah Semarang \\ 3. Mahasiswa Fakultas Kedokteran Universitas Muhammadiyah Semarang \\ Email: kantiratna@ymail.com
}

\begin{abstract}
Abstrak
Latar belakang: Angka temuan kasus diare di wilayah kerja Puskesmas Mijen, Semarang masih relatif tinggi. Salah satu penyebab penyakit diare adalah kondisi air yang tercemar sumber pengotoran seperti dekatnya jarak sumber air dengan septic tank. Escherichia coli merupakan bakteri yang mungkin ditemukan pada air yang tercemar sumber pengotoran. Cakupan bidang kesehatan lingkungan dalam hal pengawasan dan pengendalian kualitas air di wilayah kerja Puskesmas Mijen secara kseluruhan masih jauh dari capaian target, berdasarkan data tersebut maka perlu dilakukan penelitian mengenai analisis jarak septic tank dengan sumber air rumah tangga terhadap adanya bakteri Escherichia coli.

Metode: Penelitian ini merupakan studi crossectional yang dilakukan di wilayah kerja Puskesmas Mijen. Pengambilan sampel menggunakan metode systematic random sampling pada 10 kelurahan yang masuk dalam wilayah kerja dengan penentuan besaran sampel menggunakan rumus estimasi proporsi. Uji laboratorium kadar bakteri Escherichia coli dalam air dilakukan di laboratorium Fakultas Kedokteran Universitas Muhammadiyah Semarang. Data dianalisis menggunakan uji chi square.
\end{abstract}

Hasil: Dari 36 sampel air di dapatkan hasil tidak terdapat hubungan yang signifikan antara jarak septic tank dengan sumber air rumah tangga terhadap adanya bakteri Escherichia coli (P-value $=0,2$ ).

Kesimpulan: Jarak septic tank dengan sumber air rumah tangga tidak berhubungan dengan temuan bakteri Escherichia coli pada air rumah tangga di wilayah kerja Puskesmas Mijen.

Kata kunci: air rumah tangga, septic tank, Escherichia coli 


\begin{abstract}
Background: Case detection rate of diarrhea in Puskesmas Mijen, Semarang is still relatively high. One cause of diarrhea disease is a condition of polluted water sources such fouling proximity of water sources with a septic tank. Escherichia coli is a bacteria that may be found in contaminated water sources fouling. Coverage field of environmental health in terms of supervision and control of water quality in Puskesmas Mijen is still far from the achievement of the target, based on these data it is necessary to do research to analysis within a septic tank with a household water source for the presence of the bacterium Escherichia coli.
\end{abstract}

Methods: This study is a cross-sectional study conducted in Puskesmas Mijen. The study methods using systematic random sampling method in 10 villages and the sample number were included with proportion estimate formula. Laboratory tests Escherichia coli bacteria levels in the water conducted in the laboratories of the Faculty of Medicine, Universitas Muhammadiyah Semarang. Data were analyzed using chi square test.

Result: From the 36 samples of water, we get the result there is no significant relationship between the distance of a septic tank with a household water source for the presence of the bacterium Escherichia coli $(\mathrm{P}$-value $=0.2)$.

Conclusion: There is no related between the distance of the septic tank with a household water source within the findings of Escherichia coli bacteria in the household water in Puskesmas Mijen.

Keywords: household water, septic tank, Escherichia coli

\section{PENDAHULUAN}

Sumber pengotoran dapat menyebabkan kontaminasi pada air. Macam-macam sumber pengotoran antara lain jamban keluarga, septic tank, tempat pembuangan air limbah, tempat pembuangan air bekas irigasi, ${ }^{1}$ dan lubang galian sampah. ${ }^{2}$ Jarak antara lokasi sumber air dan sumber pengotoran umumnya tidak kurang dari 10 meter. $^{2}$ Air yang tercemar dapat menjadi penyebab timbulnya berbagai penyakit termasuk diare. ${ }^{1}$ salah satu bakteri penyebab diare yang berasal dari air adalah Escherichia coli. $^{3}$

Air yang dikatakan sehat harus memenuhi beberapa persyaratan seperti syarat fisik (jernih, tidak berwarna, tidak berasa, tidak berbau), syarat bakteriologis (tidak diemukan Escherichia coli maupun bakteri koliform), dan syarat kimia (tidak mengandung mineral serta zat organik dengan kadar yang lebih tinggi dari ketentuan kadar dibenarkan). ${ }^{1,2,4}$

Berdasarkan cakupan bidang kesehatan lingkungan dalam hal pengawasan dan pengendalian kualitas air di wilayah kerja Puskesmas Mijen secara kseluruhan masih jauh dari capaian target dan angka temuan kasus diare di wilayah kerja Puskesmas Mijen masih relatif tinggi, ${ }^{5}$ maka perlu dilakukan penelitian mengenai analisis jarak septic tank dengan sumber air rumah tangga terhadap adanya bakteri Escherichia coli.

\section{METODE PENELITIAN}

Penelitian ini merupakan studi crossectional yang dilakukan di wilayah kerja Puskesmas Mijen. Pengambilan sampel menggunakan metode systematic random sampling pada 10 kelurahan yang masuk dalam wilayah kerja, besaran sampel ditentukan berdasarkan rumus estimasi proporsi. Data penelitian merupakan data primer berupa wawancara menggunakan kuisioner. Sampel air yang digunakan merupakan sumber air yang digunakan masyarakat di wilayah kerja Puskesmas Mijen untuk memenuhi kebutuhan sehari-hari yang ditampung di penampungan air bawah tanah, sedangkan penilaian Escherichia coli yang gunakan adalah jumlah bakteri batang gram negatif yang terdapat didalam sampel air rumah tangga di wilayah kerja Puskesmas Mijen dengan metode MPN (Most Probable Number) yang dibandingkan dengan nilai standar syarat bakteriologis 0 bakteri Escherichia coli dalam $100 \mathrm{ml}$ air. $^{6}$ 
Uji laboratorium sampel penelitian dilakukan di laboratorium Fakultas Kedokteran Universitas Muhammadiyah Semarang yang meliputi 1). Uji praduga menggunakan medium Lactose Broth (LB); 2). Uji penegas menggunakan medium Briliant Green Lactose Bilebroth (BGLB); dan 3). Uji pelengkap dilakukan dengan cara inokulasi pada medium Eosin Methylene Blue Agar (EMBA). Data yang diperolah dianalisis menggunakan software analisis dengan uji chi square.

\section{HASIL PENELITIAN}

Dari 36 sampel yang dianalisis sebagian besar sumber air rumah tangga yang digunakan berasal dari sumur artesis sebesar 26 sampel (72,3\%), sumur gali sebesar 7 sampel (19,4\%), dan perusahaan air minum (PAM) sebesar 3 sampel (8,3\%). Sebagian besar Jarak septic tank dengan sumber air $>10 \mathrm{~m}$ sebesar 34 sampel (94,4\%) dan lebih dari setengah sampel sebesar 20 sampel (55,6\%) memenuhi syarat bakteriologis sebagai air yang sehat (tabel. 1).

Tabel 1. Karakteristik sampel air rumah tangga di wilayah kerja Puskesmas Mijen, Semarang

\begin{tabular}{|l|c|}
\hline \multicolumn{1}{|c|}{ Karakteristik sampel air } & Frekuensi (36) \\
& $\mathbf{n}(\mathbf{\%})$ \\
\hline Senis air & $7(19,4)$ \\
Artesis & $26(72,3)$ \\
PAM* & $3(8,3)$ \\
\hline Jarak septic tank dengan sumber air & $2(5,6)$ \\
$<10$ m & $34(94,4)$ \\
$>10$ m & \\
\hline Syarat bakteriologis Escherichia coli & $20(55,6)$ \\
Memenuhi (0) & $16(44,4)$ \\
\hline Tidak memenuhi ( = 1) & \\
\hline
\end{tabular}

* Perusahaan Air Minum

Dari tabel 2 dpaat dilihat hasil uji chi square bahwa tidak terdapat hubungan yang signifikan antara jarak septic tank dengan sumber air rumah tangga terhadap adanya bakteri Escherichia coli dengan p-value = 0,2 (bermakna jika $\mathrm{p}<0,05$ ). 
Tabel 2. Hubungan antara jarak septic tank dengan sumber air rumah tangga terhadap adanya bakteri Escherichia coli.

\begin{tabular}{|l|c|c|}
\hline \multirow{2}{*}{$\begin{array}{l}\text { Jarak sep tic tank } \\
\text { dengan sumber air }\end{array}$} & \multicolumn{2}{|c|}{ Syarat uji bakteriologis } \\
\end{tabular}

\section{PEMBAHASAN}

Sebagian besar sumber air rumah tangga masyarakat di wilayah kerja Puskesmas Mijen berasal dari sumur artesis. Hal ini dikarenakan wilayah Kecamatan Mijen menjadi salah satu wilayah yang diikutkan dalam realisasi Program Penyediaan Air Minum dan Sanitasi Berbasis Masyarakat (PAMSIMAS). Program ini merupakan upaya peningkatan infrastruktur air bersih di kawasan perkotaan Semarang yang berbasis pada pemberdayaan masyarakat. ${ }^{7}$ Lebih dari $90 \%$ sumber air rumah tangga di wilayah kerja Puskesmas Mijen memiliki jarak dengan septic tank $>10 \mathrm{~m}$, hal ini sesuai dengan jarak minimal air yang dikatakan bebas dari sumber pengotoran. ${ }^{2}$

Lebih dari separuh sampel memenuhi syarat uji bakteriologis yaitu tidak ditemukan bakteri Escherichia coli dalam $100 \mathrm{ml}$ air, hasil ini memenuhi syarat yang dikeluarkan Kementrian Kesehatan Republik Indonesia melalui Peraturan Menteri Kesehatan Nomor 492 Tahun 2010 (Permenkes No.492 Th.2010) mengenai persyaratan kualitas air minum. Dalam Permenkes ini disebutkan bahwa air minum dinyatakan aman bagi kesehatan jika memenuhi persyaratan fisika, mikrobiologis, kimiawi, dan radioaktif yang dimuat dalam parameter wajib maupun tambahan. Parameter mikrobiologis air meliputi tidak ditemukannya bakteri Escherichia coli dan bakteri koliform. ${ }^{6}$

Jarak septic tank dengan sumber air rumah tangga tidak berhubungan dengan temuan bakteri Escherichia coli pada air rumah tangga di wilayah kerja Puskesmas Mijen. Hasil ini berbeda dengan teori yang menyatakan semakin dekat sumber air rumah tangga dengan sumber pengotoran termasuk septic tank semakin besar kemungkinan sumber air tersebut tercemar zat pengotor. ${ }^{1}$ Septic tank merupakan cara yang paling memenuhi persyaratan dalam teknologi pembuangan kotoran manusia. Septic tank merupakan tangki sedimentasi yang kedap air, di mana tinja dan air yang masuk akan mengalami dekomposisi melalui proses kimiawi dan biologis. ${ }^{4}$ Perbedaan anatar teori dengan hasil penelitian ini kemungkinan disebabkan septic tank yang digunakan masyarakat di wilayah kerja Puskesmas Mijen memenuhi standart minimal pembuatan septic tank dan tidak terdapat kebocoran pada tangki sedimentasi. Kontaminasi bakteri Escherichia coli pada sumber air rumah tangga tidak hanya disebabkan jarak antara septic tank dengan sumber air tetapi juga dapat disebabkan sumber pengotor lain. Sumber pengotoran yang dapat berkontribusi terhadap cemaran bakteri Escherichia coli adalah tempat pembuangan air limbah, tempat pembuangan air bekas irigasi, ${ }^{1}$ dan lubang galian sampah. $^{2}$

\section{KESIMPULAN}

Jarak septic tank dengan sumber air rumah tangga tidak berhubungan dengan temuan bakteri Escherichia coli pada air rumah tangga di wilayah kerja Puskesmas Mijen sehingga perlu dilakukan penelitian lanjutan untuk mengetahui sumber cemaran bakteri Escherichia coli pada air rumah tangga di wilayah kerja Puskesmas Mijen agar seluruh sumber air di wilayah terseut meemnuhi syarat bakteriologis/ mikrobiologis sesuai Permenkes No.492 Th.2010. 


\section{DAFTAR PUSTAKA}

1. Mubarak WI, Chayatin N. Ilmu kesehatan masyarakat teori dan aplikasi. 2009. Jakarta: Salemba Medika, 289-309.

2. Entjang I. Ilmu kesehatan masyarakat. 2000. Bandung: Citra aditya bakti, 74-78.

3. Sudoyo AW,Setiyohadi B, Alwi I, Simadibrata M, Setiati S. Buku ajar ilmu penyakit dalam jilid III edisi IV. 2006.

4. Notoatmodjo S. Penyediaan air bersih dalam Kesehatan masyarakat ilmu dan seni. 2007. Jakarta: Rieka Cipta.. Halm. 172-180.

5. Puskesmas Mijen. Rancangan Tahunan Puskesmas Mijen, Semarang 2014.

6. Kementrian Kesehatan Republik Indonesia. Peraturan Menteri Kesehatan Nomor 492 / Menkes / Per / IV / 2010 tentang Persyaratan Kualitas Air Minum. 2010.

7. Astuti MT, Rahdriawan M. Evaluasi pengelolaan program pamsimas di lingkungan permukiman Kecamatan Mijen, Semarang. Jurnal Teknik PWK Volume 2 Nomor 4 2013, 938-947.http:// ejournals1.undip.ac.id 